Available online at www.ktu.edu.gh

International Journal

\title{
Assessment of Work-Based Competencies Required of Secondary School Teachers in Undergraduate Business Education Curriculum in South-West, Nigeria.
}

\author{
Okeke Blessing O. ${ }^{1}$ and Mojekwu J. N. ${ }^{2}$ \\ 1 Department of Arts and Social Sciences Education \\ University of Lagos, Lagos, Nigeria \\ 08038321141 \\ Email: royalkingbo@gmail.com, \\ ${ }^{2}$ Department of Insurance and Actuarial Sciences \\ University of Lagos, Lagos, Nigeria \\ 08033063363 \\ Email:jnmoje@yahoo.com
}

\begin{abstract}
Business Education graduates are expected to acquire high level of competencies in all aspects of human endeavour. However, this expectation seems to be lacking in the job performances of these graduates in the world of work. This study assessed the work-based competencies of Business Education teachers in public secondary schools in South-West Nigeria. The theoretical underpinnings of this study were premised on CIPP Evaluation Model. The study adopted descriptive survey research design. The population of the study comprised all Business Education teachers in public secondary schools in South-West, Nigeria. Multi-stage sampling technique was used to select 420 Business Education teachers as a study sample. Two research questions were raised and answered while one hypothesis was formulated and tested at 0.05 level of significance. The research instrument used for data collection were structured Questionnaire. The data generated were analysed using descriptive statistics such as mean and standard deviation. Furthermore, t-test was used to test the hypotheses. Findings showed that teachers acquired competencies from Business Education programme were lower than work-based required competencies. Based on the findings, this study concluded that the contents of Business Education programme do not provide students with adequate job competencies for them to perform at the level expected of them after graduation. The study recommends that Business Education programme should be reviewed and restructured so as to enable the graduates respond to social goals, economic realities and future life challenges.
\end{abstract}

Keywords: Keywords: Work-based competencies; Business Education; Business Education teachers; Business Education Programme; Job performance.

Citation: Okeke Blessing O, Mojekwu J. N. Assessment of Work-Based Competencies Required of Secondary School Teachers in Undergraduate Business Education Curriculum in South-West, Nigeria. 2020; 5 (2): 1-9.

Received: August, 2018

Accepted: June 30, 2020 


\subsection{Introduction}

As one of the most significant resources in teaching and learning contexts, teachers are critical to raising education standards. Improving the efficiency and equity of schooling depends, to a large extent, on ensuring that the teachers are highly competent, to perform at their best. Raising teaching performance is perhaps the policy direction most likely to lead to substantial benefits in student learning (OECD, 2005). This becomes imperative for higher institutions of learning to prepare students with high performance competencies that will enable them to find job as well as cope with the unpredictable labour market changes. According to the International Labour Organisation (ILO, 2002) developing young people's employability is a key policy issue for ensuring their successful transition to the labour market and their access to carrier oriented employment.

One of the major concerns of employers of labour in this information age is the recruitment of employees with required employability competencies to fit into the various organization job vacancies and positions (Okoye, 2000). Hillage and Pollard (1998), noted that employability is all about work and the performance ability to be employed. It also refers to a person's performance capability of securing and maintaining an employment. In Business Education, employability not only depends on whether one is able to fulfil the paper requirements of specific jobs. It also connotes how one practically stands out in relation to others within a group of job seekers. In other words, employability describes the possession of the required job performance competencies by business education graduates.

Competency, commonly referred to as job competencies, refer to the core skills, knowledge, abilities and attitudes (behaviours) that contribute to high performance in a given position in an organization. Competencies help organisations to achieve the productivity, innovation and profitability needed to compete effectively (Imeokparia, 2012). Competencies help public services and individuals to provide the quality and choice that people want and also raise their employability and achieve their ambitions for themselves, their families and their communities. Competencies underpin labour market flexibility.

Okorie (2000) observes that most Nigerian educational institutions of learning do not provide their students with adequate training to acquire competencies that will equip them for productive work. Those who lack sufficient competencies live on the subsistence level, and often out of desperation and frustration, constitute a nuisance to the society. Therefore, for education to be meaningful, functional and relevant to the demands of the present-day world of work, educational institutions need to give their students a system of education which should be joboriented.

Business Education programme falls under the purview of Technical and Vocational Education which prepares its recipients to earn a living in an occupation where success depends largely on technical information and understanding of the laws of sciences as applied to modern designs, production, distribution and services (Osuala, 2004). Technical and Vocational Education and Training (TVET) is a comprehensive term. It refers to those aspects of the educational process involving, in addition to general education, the study of technological and related sciences. Other relevant aspects include the acquisition of practical skills, attitudes, understanding and knowledge relating to occupations in various sectors of economic and social life.

Business Education curriculum programme is aimed at providing six components such as accounting education, office/secretarial education, marketing/distribution education as well as teaching practice and industrial work experience. The programme, also, provides its recipients with teaching mastery in business subjects; necessary components in professional education; functional general education for life, skill to undertake research and afford additional learning experiences through in-service programme. The graduate should be able to design facilities to record, report, analyse and interpret as well as teach financial information.: typing skills, shorthand skills, word processing, marketing Knowledge, Office technology management, basics of personal finance, management skill, the decision-making techniques needed to be wise consumers, the economic principles of an increasingly international marketplace, the processes by which businesses operate solid educational foundation and attitudes.

As an integral part of vocational and technical education, Business Education is subject to constant social changes, technical development and organisational demands. The increased use of new information and communication technologies and the changing perspective on employees is flexible (Achtenhagen, Grub \& Richardson 2001). As a response to these changing professional demands, a competence-based qualification structure has been adopted in 
Vocational Education in the Netherlands, Germany, France, Great Britain and Australia. (Achtenhagen et al. 2001). However, this same has not been seen in Nigeria going by the literature reviewed and the constant call for retraining of Business Education teachers by various employers of labour in Nigeria. It is on these premises that the researcher assessed the work-based competencies of Business Education teachers in order to be acquainted with the reasons for their poor performances in their work places.

\subsection{Statement of the Problem}

Business Education programme is concerned with developing individuals and students with skills and competencies required for effective participation in the business world. These competencies are made available either for enabling the individuals to be good consumers of products of the business enterprise and entry into business community as employers or employee and also as Business teachers and lecturers. Despite these laudable objectives, there is poor performance amongst Business Education teachers in their work places (Robert, 2016). As the society is becoming mobile and globalised, the pace in which the labour market is accelerating seems to be making work-place, increasingly, a high-technology and service-oriented arena Continuing with this poor performance in their work places would lead to low output and subsequently, termination of employment. This situation, if not checked, may lead to folding up of companies and total collapse of the economy (Caird, 1992). Thus, there is a need to assess the work-based competencies of Business Education teachers.

\subsection{Purpose of the Study}

The purpose of the study is to assess the work-based competencies of Business Education teachers in secondary schools, South-West, Nigeria.

The specific objectives are to:

i. identify the work-based competencies (Knowledge, Skills and attitude) required of Business Education teachers;

ii. compare the work-based required knowledge of Business Education teachers with the one developed from the Business Education programme;

\subsection{Research Questions}

The following research questions were raised:

i. What are the work-based required competencies (Knowledge, Skills and attitude) of Business Education teachers?

ii. To what extent do work-based required knowledge competence relate to Business Education teachers' acquired knowledge competence from Business Education Programme?

\subsection{Research Hypothesis}

There is no significant difference between work-based required knowledge competencies and Business Education teachers' acquired knowledge competencies from business Education Programe.

\subsection{Methodology}

\subsection{Research Design}

Descriptive Survey research design was used.

\subsection{Research Population}

All Business Education teachers teaching Business Education subjects in public secondary schools in South-West, Nigeria.

\subsection{Sample and Sampling Techniques}

Multi-stage sampling was adopted in the study. 
Stage 1: Purposive sampling technique was applied to select Lagos, Ogun and Ekiti States as the study sample. This is because these three states have enough statistics.

Stage 2: Simple random sampling technique was used to select four local government areas each from the three selected States to obtain 12 Local Government Areas

Stage 3: Systematic sampling method was adopted to select 7 schools from each of the selected Local Government Areas, resulting to a total of 84 public secondary schools.

Stage 4: Finally, from each of the selected schools, proportionate stratified sampling method was applied to select 5 Business Education teachers to arrive at a sample size of 420 . The stratification was based on the sex of the respondents. Yamane (1967) was used to determine the sample size.

$$
\begin{aligned}
& \mathrm{n}=\frac{N}{(1+N) e^{2}} \\
& \mathbf{n}=\text { sample size } \\
& \mathbf{N}=\text { the population of the size } \\
& \mathrm{e}=\text { error margin }(0.05)
\end{aligned}
$$

\subsection{Research Instruments for Data Collection}

The data for the study were generated through Structured Questionnaire tagged Required and Acquired Competency Assessment Questionnaire for Teachers (RACAQT). The questionnaire contained 9 items on the Competencies Acquired and Required of Business Education teachers, (CARAQ). The second questionnaire contained 30 items which assessed the knowledge competence in the three domains of Business Education. Respondent were required to respond on four-Likert scale of Highy Required (HR) $=4$, Averagely Required (AR) $=3$, Least required $(\mathrm{LR})=2$, Not required $(\mathrm{NR})=1$ and Highly Acquired $(\mathrm{HR})=4$, Averagely Acquired $(\mathrm{AA})=3$, Least Acquired (LA) $=2$, Not Acquired (NA) $=1$.

\subsection{V alidity of Research Instruments}

The content and face validity of the instruments were determined by the researcher's supervisors and other experts in the field of Business Education and evaluation.

\subsection{Reliability of the Instruments}

The reliability of the instruments was determined using Cronbach's Alpha and Guttman Split half coefficient test of reliability to ensure reliability at alpha level of 0.05

\subsection{Procedure for Data Collection}

The respondents with the help of three research assistants were administered on one-to one basis and collected on the spot as they were filled out and so there were $100 \%$ return.

\subsection{Method of Data Analysis}

Descriptive and inferential statistical methods were used to analyse all the data generated from the study. Research questions were analysed using descriptive statistical tools such as mean and standard deviation and t-test inferential statistical tool was used to test the formulated hypothesis.

\section{Results}

Research Questions 1: What are the work-based required competencies of Business Education Teachers? Table 1: Ranking of Respondents' Opinions on the Required Work-based Competencies

\begin{tabular}{lllllll}
\hline S/N & $\begin{array}{l}\text { Work-based Required of Business } \\
\text { Education Teachers }\end{array}$ & Mean & $\begin{array}{l}\text { Standard } \\
\text { Deviations. }\end{array}$ & $\begin{array}{l}\text { Coeff. of } \\
\text { Variation }\end{array}$ & Remarks & $\begin{array}{l}\text { Ran } \\
\mathbf{k}\end{array}$ \\
\hline $\mathbf{1}$ & Teaching Skills & 3.839 & .267 & 6.95 & Required & $1^{\text {st }}$ \\
$\mathbf{2}$ & ICT Skill Competencies & 3.808 & .334 & 8.77 & Required & $2^{\text {nd }}$ \\
\hline
\end{tabular}




\begin{tabular}{|c|c|c|c|c|c|c|}
\hline 3 & Communication Skills competencies & 3.796 & .341 & 8.98 & Required & $\overline{4^{\text {rd }}}$ \\
\hline 4 & Interpersonal Skill Competencies & 3.700 & .329 & 8.89 & Required & $3^{\text {th }}$ \\
\hline 5 & $\begin{array}{l}\text { Knowledge of Marketing Competencies } \\
\text { (course content) }\end{array}$ & 3.661 & .439 & 11.99 & Required & $8^{\text {th }}$ \\
\hline 6 & $\begin{array}{l}\text { Office Technology Management } \\
\text { Competencies (course content) }\end{array}$ & 3.435 & .375 & 10.92 & Required & $6^{\text {th }}$ \\
\hline 7 & $\begin{array}{l}\text { Knowledge of Accounting Competencies } \\
\text { (course content) }\end{array}$ & 3.333 & .311 & 9.33 & Required & $5^{\text {th }}$ \\
\hline 8 & Managerial Skills Competencies & 3.001 & .355 & 11.82 & Required & 7 th \\
\hline 9 & Attitude (Commitments) & 2.909 & .379 & 13.03 & Required & $9^{\text {th }}$ \\
\hline
\end{tabular}

The data presented in Table 1, indicates that the respondents are of the opinion that all statement items 1 to 9 with mean scores ranging from 2.909 to 3.839. The study reveals that all the competencies listed are considered highly required by the respondents.

Research Question 2: To what extent does work-based required knowledge competence relate to Business Education teachers acquired knowledge competence from Business Education Programme (in Accounting, Office Technology Management (OTM) and Marketing)?

Table 2: Opinion of the Respondents on the Extent of Work-based Required Knowledge Relate to Business Education Teachers Acquired Knowledge (accounting option).

\begin{tabular}{|c|c|c|c|c|c|c|}
\hline \multirow{2}{*}{$\begin{array}{l}\mathbf{N} \\
\mathbf{S}\end{array}$} & \multirow{2}{*}{$\begin{array}{l}\text { Items } \\
\text { Knowledge of Accounting Contents of } \\
\text { Business Education graduates. }\end{array}$} & \multicolumn{2}{|c|}{$\begin{array}{l}\text { Work-based Required } \\
\text { Competencies }\end{array}$} & \multicolumn{2}{|c|}{$\begin{array}{l}\text { Business Education } \\
\text { Graduates Acquired } \\
\text { Competencies }\end{array}$} & \multirow[t]{2}{*}{$\begin{array}{c}\text { Mean } \\
\text { Dif. }\end{array}$} \\
\hline & & Mean & Std. Dev. & Mean & Std. Dev. & \\
\hline 1 & $\begin{array}{l}\text { Ability to reconcile Bank statement with } \\
\text { organizational cash book. }\end{array}$ & 3.471 & 0.241 & 2.355 & 0.171 & 1.116 \\
\hline 2 & Application of accounting principles. & 3.349 & 0.274 & 2.208 & 0.263 & 1.141 \\
\hline 3 & $\begin{array}{l}\text { Preparation of simple trading, profit and loss } \\
\text { account. }\end{array}$ & 3.238 & 0.270 & 2.276 & 0.279 & 0.962 \\
\hline 4 & $\begin{array}{l}\text { Preparation of partnership account including } \\
\text { admission of partners, appropriation of profit, } \\
\text { current and capital account and dissolution of } \\
\text { partnership }\end{array}$ & 3.231 & 0.279 & 2.197 & 0.240 & 1.034 \\
\hline 5 & $\begin{array}{l}\text { Ability to sort and classify assets, capital and } \\
\text { liability as well as revenue and expenditure. }\end{array}$ & 3.093 & 0.291 & 2.005 & 0.216 & 1.088 \\
\hline 6 & $\begin{array}{l}\text { Ability to close or balance off ledger accounts } \\
\text { and transfer to trial balance. }\end{array}$ & 3.015 & 0.207 & 2.146 & 0.209 & 0.869 \\
\hline 7 & Ability to post and maintain ledger accounts. & 2.911 & 0.262 & 1.765 & 0.332 & 1.146 \\
\hline 8 & $\begin{array}{l}\text { Ability to treat accruals, prepayments, discounts, } \\
\text { bad debts and depreciation }\end{array}$ & 2.889 & 0.315 & 1.952 & 0.215 & 0.937 \\
\hline 9 & $\begin{array}{l}\text { Preparation of accounts of non-profit making } \\
\text { organization. }\end{array}$ & 2.881 & 0.256 & 1.532 & 0.296 & 1.349 \\
\hline \multirow[t]{2}{*}{10} & $\begin{array}{l}\text { Ability to value stock using FIFO, LIFO and } \\
\text { AVCO (methods). }\end{array}$ & 2.795 & 0.402 & 1.234 & 0.208 & 1.561 \\
\hline & Average & 3.087 & 0.278 & 1.967 & 0.243 & 1.1203 \\
\hline
\end{tabular}


Table 3: Opinion of the Respondents on the Extent Work-based Required Knowledge Relate to Business Education Teachers Acquired Knowledge (office technology management).

\begin{tabular}{|c|c|c|c|c|c|c|}
\hline \multirow{3}{*}{$\begin{array}{l} \\
\mathbf{S} / \\
\mathbf{N}\end{array}$} & \multirow{3}{*}{$\begin{array}{l}\text { Items } \\
\text { Knowledge of Office Technology } \\
\text { Management Contents of Business } \\
\text { Education Graduates. }\end{array}$} & \multicolumn{2}{|c|}{$\begin{array}{l}\text { Work-based Required } \\
\text { Competencies }\end{array}$} & \multicolumn{2}{|c|}{$\begin{array}{l}\text { Bus Education } \\
\text { Graduates Acquired } \\
\text { Competencies } \\
\end{array}$} & \multirow[t]{3}{*}{$\begin{array}{l}\text { Mean } \\
\text { Dif. }\end{array}$} \\
\hline & & \multirow[t]{2}{*}{ Mean } & \multirow[t]{2}{*}{ Std. Dev. } & \multirow[t]{2}{*}{ Mean } & \multirow[t]{2}{*}{ Std. Dev. } & \\
\hline & & & & & & \\
\hline 1 & $\begin{array}{l}\text { Ability to use ICT equipment for } \\
\text { communication }\end{array}$ & 3.432 & 0.417 & 2.632 & 0.530 & 0.800 \\
\hline 2 & $\begin{array}{l}\text { Ability to manage information at the right } \\
\text { time }\end{array}$ & 3.245 & 0.291 & 2.412 & 0.445 & 0.833 \\
\hline 3 & $\begin{array}{l}\text { Ability to recognize office automation } \\
\text { system }\end{array}$ & 3.212 & 0.398 & 2.453 & 0.477 & 0.759 \\
\hline 4 & $\begin{array}{l}\text { Ability to communicate effectively using } \\
\text { oral and written skills. }\end{array}$ & 3.099 & 0.345 & 2.444 & 0.416 & 0.655 \\
\hline 5 & Ability to conduct meetings, wisely. & 3.001 & 0.447 & 2.378 & 0.438 & 0.623 \\
\hline 6 & $\begin{array}{l}\text { Ability to plan for short, medium and } \\
\text { long-term }\end{array}$ & 2.991 & 0.221 & 2.307 & 0.342 & 0.684 \\
\hline 7 & $\begin{array}{l}\text { Ability to purchase goods, tools and } \\
\text { equipment. }\end{array}$ & 2.723 & 0.423 & 2.583 & 0.439 & 0.14 \\
\hline 8 & $\begin{array}{l}\text { Ability to acquire management and } \\
\text { supervisory skills. }\end{array}$ & 2.686 & 0.338 & 2.479 & 0.414 & 0.207 \\
\hline 9 & $\begin{array}{l}\text { Ability to recognize need for employees } \\
\text { growth and development }\end{array}$ & 2.644 & 0.518 & 2.393 & 0.316 & 0.251 \\
\hline \multirow[t]{2}{*}{10} & Ability to determine and fix personal salary & 2.635 & 0.422 & 2.436 & 0.487 & 0.199 \\
\hline & Average & 2.967 & 0.382 & 2.452 & 0.430 & 0.515 \\
\hline
\end{tabular}

Table 4: The Extent Work-Based Required Knowledge Relate to Business Education Teachers Acquired Knowledge (Marketing Option).

\begin{tabular}{|c|c|c|c|c|c|c|c|}
\hline \multirow[t]{2}{*}{$\mathbf{S} / \mathbf{N}$} & \multirow[t]{2}{*}{ Items (Marketing/sales) } & \multicolumn{3}{|c|}{$\begin{array}{l}\text { Job place } \\
\text { Required } \\
\text { Competencies }\end{array}$} & \multicolumn{2}{|c|}{$\begin{array}{l}\text { Curriculum } \\
\text { Acquired } \\
\text { Competencies }\end{array}$} & \multirow{2}{*}{$\begin{array}{l}\text { Mean } \\
\text { Diff }\end{array}$} \\
\hline & & Mean & $\begin{array}{l}\text { Std. } \\
\text { Dev. }\end{array}$ & Rank & Mean & Std. Dev. & \\
\hline 1. & Knowledge of advertising & 2.989 & 0.301 & $1^{\text {st }}$ & 2.232 & 0.319 & 0.757 \\
\hline 2. & Knowledge of good sale technique & 2.977 & 0.344 & $2^{\text {nd }}$ & 2.516 & 0.576 & 0.461 \\
\hline 3. & $\begin{array}{l}\text { Understanding sources of business } \\
\text { risk }\end{array}$ & 2.917 & 0.319 & $3^{\text {rd }}$ & 1.978 & 0.848 & 0.939 \\
\hline 4. & $\begin{array}{l}\text { Be polite, tactful and cheerful in } \\
\text { dealing with customers }\end{array}$ & 2.899 & 0.395 & $4^{\text {th }}$ & 1.964 & 0.643 & 0.935 \\
\hline 5. & $\begin{array}{l}\text { Identify and effectively evaluate } \\
\text { business risks }\end{array}$ & 2.896 & 0.377 & $5^{\text {th }}$ & 1.643 & 0.521 & 1.253 \\
\hline 6. & $\begin{array}{l}\text { Carryout good marketing and } \\
\text { information research }\end{array}$ & 2.894 & 0.456 & $6^{\text {th }}$ & 1.692 & 0.661 & 1.202 \\
\hline 7. & $\begin{array}{l}\text { Relate risks with business objectives } \\
\text { of the enterprise. }\end{array}$ & 2.875 & 0.398 & $7^{\text {th }}$ & 1.479 & 0.557 & 1.396 \\
\hline 8. & $\begin{array}{l}\text { Boldness in making decisions and } \\
\text { willingness to assume certain risks }\end{array}$ & 2.866 & 0.45 & $8^{\text {th }}$ & 1.609 & 0.476 & 1.257 \\
\hline
\end{tabular}




\begin{tabular}{llllllll}
\hline 9. & $\begin{array}{l}\text { Determine and interpret factors } \\
\text { which indicate extent and strength of }\end{array}$ & 2.791 & 0.466 & $9^{\text {th }}$ & 1.09 & 0.529 & 1.701 \\
$\begin{array}{l}\text { competition } \\
10\end{array}$ & $\begin{array}{l}\text { Implement decisions and handle } \\
\text { risks }\end{array}$ & 2.729 & 0.492 & $10^{\text {th }}$ & 1.136 & 0.506 & 1.593 \\
$\quad$ & 2.883 & 0.400 & & 1.734 & 0.564 & 1.149 \\
\hline
\end{tabular}

The data presented in Tables 2, 3 and 4 above indicates that the respondents are of the opinion that all statement items 1 to 10 in Accounting, OTM and Marketing Domains of Business Education are highly required knowledge competencies. The study reveals that system is not providing adequate education for the challenges of the modern day work-place.

\subsection{Analysis Research Hypotheses}

Hypotheses one

In order to test the hypothesis one which states that there is no significant difference between work-based required knowledge and Business Education teachers acquired knowledge, paired sampled t-test was carried out at 5\% level of significance and the results are shown on table 5 .

Table 5: Paired sampled t-test Analysis Showing Difference in Work-based Required Knowledge competencies and Business Education Teachers Acquired Knowledge.

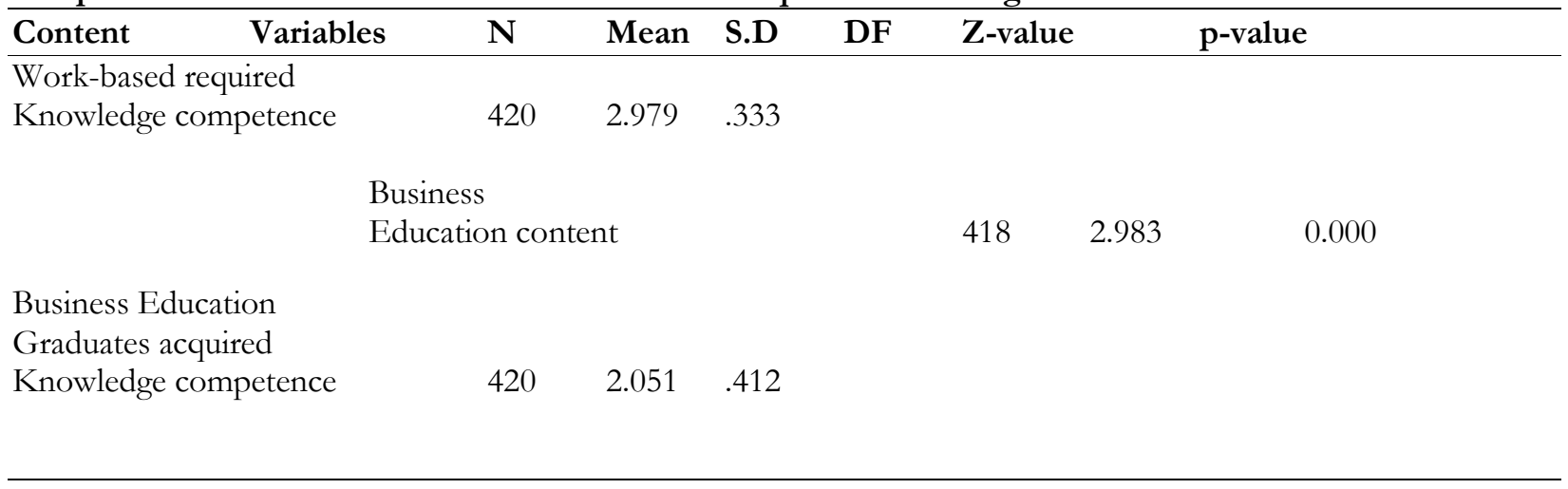

With respect to the mean scores, work-based required knowledge competencies recorded a slight higher mean $(\mathrm{M}=2.979, \mathrm{~S} . \mathrm{D}=0.333)$ than the curriculum acquired knowledge competencies $(\mathrm{M}=2.051, \mathrm{~S} . \mathrm{D}=0.412)$. The slight difference in the mean score was statistically significant as $(z-c a l=2.987, P>0.00)$ since $p=0.000$. This suggests that there is a significant difference between the work-based required knowledge and university acquired knowledge of Business Education teachers. However, to ascertain the level of differences between the required and acquired knowledge for these content areas, the mean values for the paired sample statistics are examined. Since the paired differences of the mean are all positive values, it shows that the knowledge acquired for all the areas is less than the work-based required knowledge. Hence, it can be concluded that the knowledge acquired by Business Education teachers is not adequate to meet the required work-based knowledge in the three domains of Business Education.

\subsection{Discussion of Findings}

The study reveals that all the competencies listed are considered highly required by the respondents. The skills listed are basic skills that graduates are expected to develop through their undergraduate studies. They include teaching skills, ICT skills, communication skills, interpersonal skills, managerial skills, knowledge of course content 
and attitude. Wetterman (2005) in Oduma \& Ile (2012) noted that the possession of core office occupation competencies among job applicants is vital because it could be a major source of strength and efficiency for organizations in the discharge of regular office routine functions. Locker (2000) noted that the language of electronic soft skills and competence is no longer new in the world of business. It is all about the acquisition of the skills of information and communication technology. The findings of these studies are in alliance with the findings of the present study.

\subsection{Work-based required and Business Education Teachers Acquired knowledge}

There is a general concern that the university system is not providing adequate education for the challenges of the modern day work-place as we are now living in knowledge based society (Nwaubani, 2008). The results from research question two and hypothesis one showed that there is significance different between knowledge acquired by Business Education teachers and work-based knowledge required in their places of work. This means that the knowledge acquired by the respondents is lower than knowledge required of them to work effectively. So, the null hypothesis earlier stated was rejected. Also, the mean gain of the knowledge required by the work place (mean gain=3.087,- accounting (Acc), 2.967, -OTM, and 2.883,- Marketing(MKT) was greater than that of the knowledge acquired or developed through Business Education curriculum programme (mean gain=1.967 for Acc, 2.452 for office technology management(OTM), 1.734 for MKT). This result is attributed to the complexities and dynamisms that have characterized the modern day labour market, making Knowledge the key aspect of labour market transitions. This is in consonance with International Labour Organization (ILO, 2002) which posits that developing young people's employability is a key policy issue for ensuring their successful transition to the labour market and their access to carrier oriented employment.

\subsection{Conclusion}

The study assessed the work-based competencies of Business Education teachers in secondary schools, SouthWest, Nigeria. The researcher concludes by stating that the contents of Business Education programme do not fully equip their students with adequate competencies required in 21 st century. Consequently, they cannot confidently join the labour market as teachers, compete with their mates, secure the job and perform effectively in the fieldwork. The implication of the result is that the prospect of Business Education graduate to secure job in Nigeria will be thwarted by lack of necessary competencies required by employers of labour in global economy.

\subsection{Recommendations}

In view of the issues enumerated, this study recommends that:

i. The contents of Business Education programme needs an in-depth review. This would enable the graduates respond to social goals, economic realities and future life challenges. This should be done by selecting contents that are consistent with emergent and anticipated competence needs of the society.

ii. Also to solve the problem of work-based competencies required in the 21st century, modern technology should be integrated into the contents of Business Education programme in Nigerian universities.

iii Moreover, theoretical aspects of Business Education courses should be aligned with related practical for teaching effectiveness. Therefore, the programme should be organised in a most profitable way to achieve its aims and objectives. . This will help to provide students with practical competencies needed for successful transition to work place. 


\section{References}

1. Achtenhagen, F., Grubb, W. N. \& Richardson, V. (2001). Vocational and occupational education: Pedagogical complexity, institutional diversity. Handbook of research on teaching, 4, 604-639 and approaches. Benin City, Nigeria.

2. Ekpenyong, L. E. (2005). Foundations of Technical and vocational education: New directions

3. Hillage, J., \& Pollard, E. (1998). Employability: developing a framework. for policy analysis. London: DfEE.

4. ILO (2002), Youth and work: Global trends, Report prepared jointly by the ILO Employment Sector (InFocus Programme on Skills, Knowledge and Employability, and the Key Indicators of the Labour Market) and the ILO Bureau of Labour Statistics.

5. Imeokparia, P.O and Ediagbonya, K. (2012). Employability of Business Education Teachers. Educational Research 3(8), Retrieved From http://www.interesjournals.org/ on 12th March, 2015.

6. Nwaubani, O. O. (2008). Towards a competency-based social studies teacher education programme; policy options and implications for education sector reforms in Nigeria. Education sector reform in Nigeria: what? why? how? and sustainability, 144.

7. Oduma, C. A., \& Ile, C. M. (2012). Office Employability Competencies Needed by Business Education Graduates for Effective Job Performance in Modern Organisations in Nigeria. AFRREV IJAH: An International Journal of Arts and Humanities, 1(2), 211-223.

8. OECD. Career guidance and public policy: bridging the gap. Paris: OECD, 2005.

9. Okoye, F.C. (2000). Organizational management. Ibadan: Hcbn pub.co

10. Okorie, J. U. (2000). Developing Nigeria's workforce. Calabar: page environs Publishers.

11. Osuala, E. (2004). Foundations of Vocational Education. 5th: Cheston Agency Limited: Enugu.

12. Robert, M. K. (2016). Pedagogical Challenges Facing the Teaching of Business Studies and Impact on students' Achievement in Secondary Schools in Nyandarua County- Kenya 19-20.

13. Yamane, T. (1967). Elementary sampling theory. 